\title{
Application of fluorescent light microscopy to enhanced microfacies analysis of Jurassic carbonate rocks, SE Bohemian Massif
}

\author{
Využití fluorescenční mikroskopie při studiu mikrofaciálních typů karbonátových hornin \\ jv. okraje Českého masivu
}

Lukáš Jurenka1, 2 , Juraj Franců ${ }^{2} \rightarrow$

${ }^{1}$ Faculty of Science, Masaryk University, Kotlářská 2, 61137 Brno, Czech Republic

${ }^{2}$ Czech Geological Survey, Leitnerova 22, 65869 Brno, Czech Republic

\section{Key words:}

Jurassic, Vranovice Formation, Carbonates, Dolomites, Diagenesis, Fluorescence

$\square$ juraj.francu@geology.cz

Editor:

Pavla Tomanová Petrová
Recommended reference:

Jurenka, L., Franců, J. (2020).

Application of fluorescent light microscopy to enhanced microfacies analysis of Jurassic carbonate rocks, SE Bohemian Massif. - Geological Research in Moravia and Silesia, 27, 1-2, 106-110.

\begin{abstract}
Upper Jurassic limestones and dolomites of the Vranovice Formation occur on the southeastern slopes of the Bohemian Massif below the Western Carpathian thrust belt. They represent a special type of reservoir rocks in the potential geothermal systems and exhibit highly variable porosity, permeability, and flow mechanisms due to different type of diagenesis and pervasive dolomitization. Fluorescence and translucent light microscopy was used for more detailed petrographic analysis of Vranovice limestones and dolomites. Isopachous, syntaxial and dolomitic cements were distinguished along with fossils recrystallization. Two generations of dolomite were identified - replacement dolomite and zonal cementation dolomite, what suggests a number of changes in the formation water chemistry during the dolomitization process. Extent of the observed dolomitization is inversely related to the porosity of the Jurassic rocks. Postdiagenetic generation of fissures cutting the strata due to tectonic deformation is documented by bright fluorescent color. In the studied samples of Vranovice limestones and dolomites the fissures represent the most important migration pathways, more than pore throats themselves. Further genetic information on petroleum migration is interpreted from intercrystalline porosity filled with precipitated solid bitumen. Present results provide basis for further investigations in pore-water-rock interactions and changes in chemical conditions during diagenesis.
\end{abstract}

\begin{abstract}
Abstrakt
Svrchně jurské vápence a dolomity vranovického souvrství se nacházejí jako autochtonní relikty na jv. okraji Českého masivu, pod př́krovy Západních Karpat. Představujíspeciální typ rezervoárových hornin s velmi promènlivou porozitou a propustností. Petrofyzikální vlastnosti hornin vranovického souvrství jsou do značné míry ovlivněny diagenezí a dolomitizací. Pro detailnější petrografické analýzy těchto hornin je použita fluorescenční mikroskopie a mikroskopie v procházejícím světle. Je identifikováno několik typů cementů - izopachový, syntaxiální a dolomitický. Vyskytují se dvě generace dolomitu - náhražkový („,replacement") dolomit a zonální cementační dolomit, které pravděpodobně predstavují ranou diagenezi a pozdějši fázi preměny spojenou s hlubším pohřbením a zvýšenými teplotami. Jsou pozorovány prípady prostorové spojitosti rủstu cementačního dolomitu s póry $v$ jurských horninách. Pukliny, které reprezentují nejdůležitější migrační cesty ve sledovaných horninách, jsou charakteristické výraznou fluorescencí použitého polyesteru. Jejich vznik lze prìradit k pozdèjším tektonickým deformacím. U jednoho ze studovaných vzorků jsou viditelné póry mezi krystaly vyplněny pevným bitumenem s charakteristickou žlutooranžovou fluorescencí. Indikují migraci uhlovodíkủ rozpukanými karbonátovými horninami. Současné výsledky poskytují základ k dalšímu studiu interakcí pór-voda-hornina a změnám chemických podmínek během diageneze.
\end{abstract}




\section{Introduction}

Economic importance of carbonate rocks as ground water, geothermal water, and oil- and gas reservoirs depends very much on the state of preservation of the original porosity, as well as on the state of secondary porosity during diagenesis due to mineral transformations, such as limestone dolomitization. Good understanding of the depositional environment and diagenesis of carbonates is a prerequisite of a successful geothermal ground water, as well as oil and gas exploration.

In this paper we present some observations of diagenetic features, phases of cementation and dolomitization using standard petrographic methods enhanced by fluorescent light microscopy. More information about the potential applications was published by Dravis and Yurewicz (1985).

\section{Fluorescence}

Fluorescence is a form of luminescence phenomenon and occurs when molecules absorb e. g. ultraviolet light, electron shells turn to an excited state and emit secondary fluorescent light of lower energy than the excitation light upon returning to the original state. Carbonates exhibit a variety of typical green color fluorescence when irradiated by blue-ultraviolet light. Fluorescence microscopy is routinely used in organic petrology for identification of lipid rich macerals and petroleum related bitumens.

\section{Method and samples}

Rock samples were impregnated by polyester resin with green fluorescence and prepared as polished thin sections. Leitz Orthoplan microscope MPV-II with Ploemopak fluorescence module was used with blue- violet excitation light of $400 \mathrm{~nm}$ wavelength, dichromatic mirror $510 \mathrm{~nm}$ to remove the low wavelength light, and finally a $510 \mathrm{~nm}$ barrier filter to remove the excitation light from the outgoing light. The microscope was equipped with a XBO 450 xenon lamp.

24 core samples were provided by the MND Company and analyzed by the Czech Geological Survey.
Tab. 1: Sample description: well name and number, $\mathrm{x}, \mathrm{y}, \mathrm{z}$ coordinates (JTSK), measured depth.

\begin{tabular}{|l|c|c|c|c|c|}
\hline Well & Y_S-JTSK & X_S-JTSK & $\begin{array}{c}\text { Z } \\
\text { (m ASL) }\end{array}$ & $\begin{array}{c}\text { Core } \\
\text { No. }\end{array}$ & $\begin{array}{c}\text { Measured } \\
\text { depth (m) }\end{array}$ \\
\hline KOE6 & 580601.93 & 1176814.31 & 355.67 & 9 & 1379 \\
\hline UH4 & 569844.30 & 1179596.50 & 211.80 & 4 & 1580 \\
\hline UH5 & 571076.01 & 1179721.54 & 257.85 & 4 & 1779 \\
\hline
\end{tabular}

Three selected samples of the UH4, UH5 (Uhřice), KOE6 (Koberice) wells are discussed in this paper (Tab. 1).

The rocks belong to the Vranovice Formation of the Upper Jurassic age (Eliáš 1974; Adámek 2005; Řehánek 2000) deposited on the SE margin of the Bohemian Massif in an area adjacent to the Nesvačilka Graben between Brno and Hodonín. It is overlain by the nappes of the Outer West Carpathians. Lithologically they include different types of light brown, light grey to grey mudstone limestones, brownish marlstones, oolitic and organodetritic limestones of variable state of dolomitization, and dolomites. In 2001, the Žarošice oil-and-gas field was discovered in the dolomites of the mentioned formation (Pícha et al. 2006). The Vranovice Formation was deposited in the carbonate bank and slope environment during the Oxfordian and Lower Kimmeridgian (Řehánek 2000). Eliáš (1981) described eleven and Rehánek (1992) four microfacies in the Vranovice Formation.

\section{Results and Discussion}

Investigated limestones and dolomites are characterized using the microfacies classification proposed e. g. by Dunham (1962) or Sibley and Gregg (1987). The fluorescent light visualization of depositional and diagenetic features is shown on a set of three samples selected for this purpose listed in Table 1.

\section{Sample UH4: Oolitic grainstone, Vranovice Formation}

The light brownish limestone is composed mostly of ooids, cortoids and peloids, with less frequent bioclasts and intraclasts. The microfacies is identified as oolitic (sensu Rehánek 1992). The intergranular space is

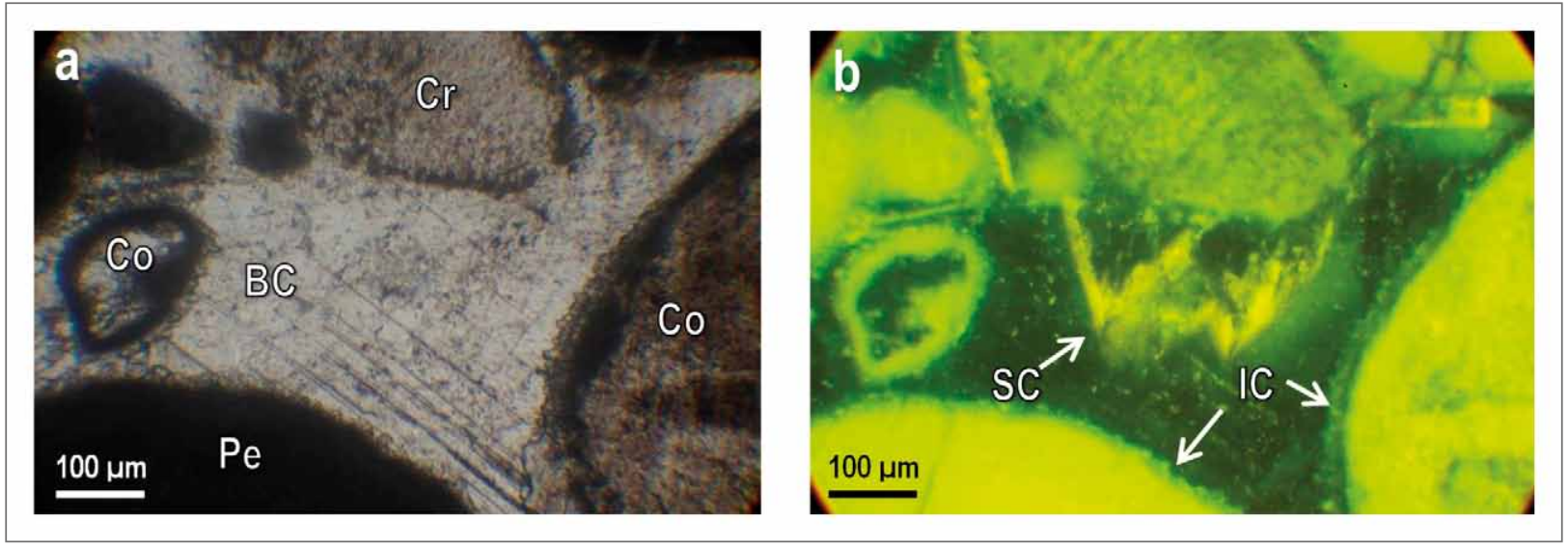

Fig. 1: UH4 - a) translucent light, b) fluorescent light (FL): cortoids - rounded skeletal allochems with distinct micrite envelope (Co), crinoid (Cr), peloid (Pe), isopachous cement (IC), syntaxial cement (SC), invisible in PPL, growing from a Crinoid allochem, blocky calcite cement (BC) filling the earlier pore space. 


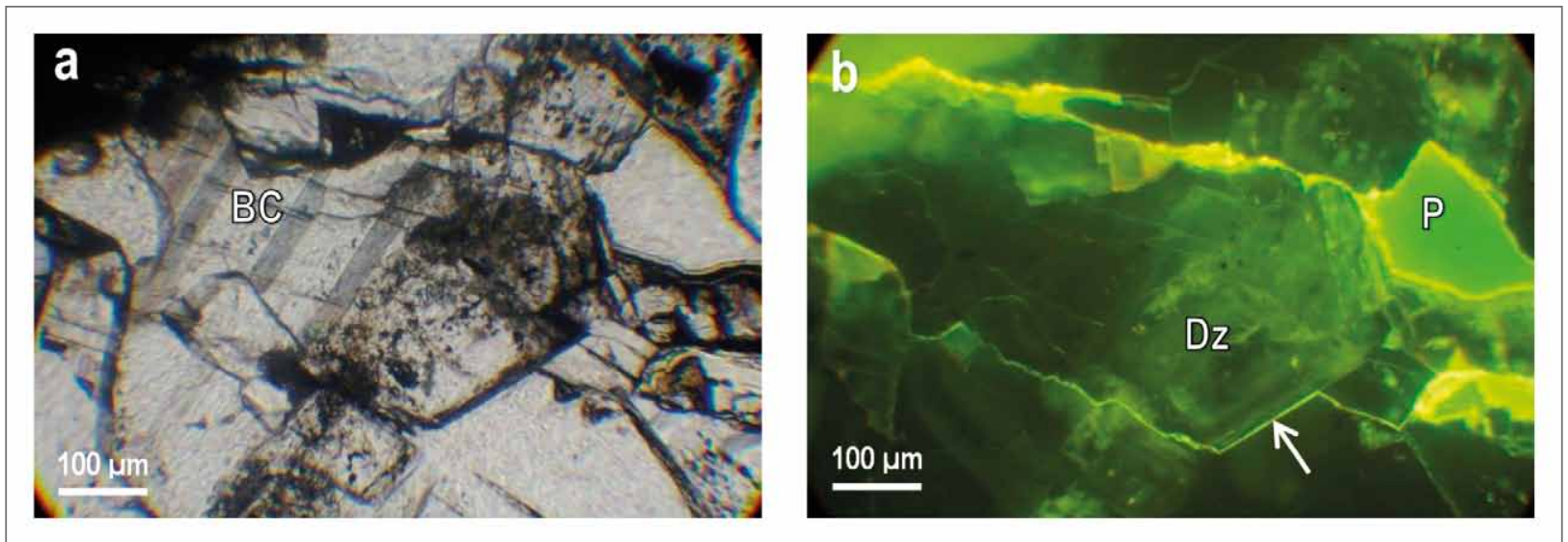

Fig. 2: UH5 - a) blocky calcite cement (BC) filling an earlier pore space, PPL, b) the same field as a) in FL: partly zonal crystal of dolomite (Dz), bright fluorescent fissure filled with epoxy resin marks the margin of a zonal dolomite crystal (arrow), pore (P) is open.

completely filled by three types of calcite cement identified using fluorescent light microscopy (Fig. 1):

- isopachous cement grown as a thin layer directly on the ooid, cortoid and peloid grains;

- syntaxial cement with a zonal texture in fluorescent light grown on crinoid grains, dark zone occurs directly on the crinoid allochems and sharply changes to a light zone on the outer edge of the crystals; presence of the syntaxial cement was confirmed in crossed nicols polarized light (XPL);

- blocky calcite cement, with faint zonal texture filling the remaining intergranular space;

- isopachous and syntaxial cement probably formed shortly after sediment deposition, during shallow burial and compaction, as can be inferred based on presence or absence of this type of cement at the grain contact, which are often pressure deformed. Formation of the blocky calcite cement is interpreted as a later phase, which filled the remaining intergranular space. In some cases, this type of cement partly replaces syntaxial cement. The rock became fully impermeable.

\section{Sample UH5: Dolomitic limestone (Packstone), with a unimodal, planar-s to planar-e dolomite, Vranovice Formation}

Light grey limestone is composed mainly of micrite with radiolarians, sponge spicules, peloids, pseudo-ooids, crinoids, ostracods, and calcispheres. The rock corresponds to the bioclastic microfacies with peloids and cortoids (Řehánek 1992). The pore space is filled with a blocky calcite and the rock is rich in branched stylolites filled with fine-grained dolomite. In fluorescent light the dolomite is partly zonal with alternating lighter and darker zones (Fig. 2). Dolomite formation occurred after the blocky calcite cementation of the pore space. Reduction of crystal volume during dolomitization resulted in formation of voids and fissures next to the dolomite grains and to increase of porosity and permeability of the limestone (Fig. 2).

\section{Sample KOE6: Polymodal, planar-s to planar-e dolomite with replacement dolomite and cementation dolomite}

Macroscopically the rock is dark grey with white mottles and pyritized layers. Matrix texture is crystalline with recrystallized allochems. Dolomite crystals grow into frequent cavernous and mold-pores. Originally, the rock was deposited as packstone. Due to high recrystallization it is difficult to specify the microfacies.

Fluorescent microscopy revealed at least two generations of dolomite. The first one occurs as a non-zonal dolomite (replacement dolomite), which replaces allochems and micrite. Remains of allochems and micrite are frequently preserved in dolomite crystal cores as dark inclusions. The other generation is zonal cementation dolomite, growing on non-zonal (replacement) dolomite or in free pore spaces. It is better identifiable in fluorescent light (Fig. 3).

During the first-phase of dolomitization, a large amount of calcite was "consumed" by dolomite and abundant new pores, due to dissolution and recrystallization were formed. The pores were later filled or were lined with next generation of zonal dolomite cement. Both types of dolomite are divided by a clear light/dark boundary (Fig. 3d). Zonation of the cementation dolomite most probably reflects changes in pore water chemistry. In addition to the cavernous and mold porosity the fluorescent light microscopy made it possible to identify an inter-crystalline porosity and occurrence of solid bitumen between the grains marked by orange-yellow color (Fig. 3b). The bitumen is interpreted as an evidence of oil migration prior to the final cementation.

\section{Conclusions}

- Fluorescent light microscopy offers new possibilities in interpretation of carbonate rocks depositional environment, diagenesis, pore space and permeability evolution, which are of primary importance for evaluation of the geothermal energy and oil and gas potential. The first results of the investigation of the Vranovice Formation can be summarized as follows: 

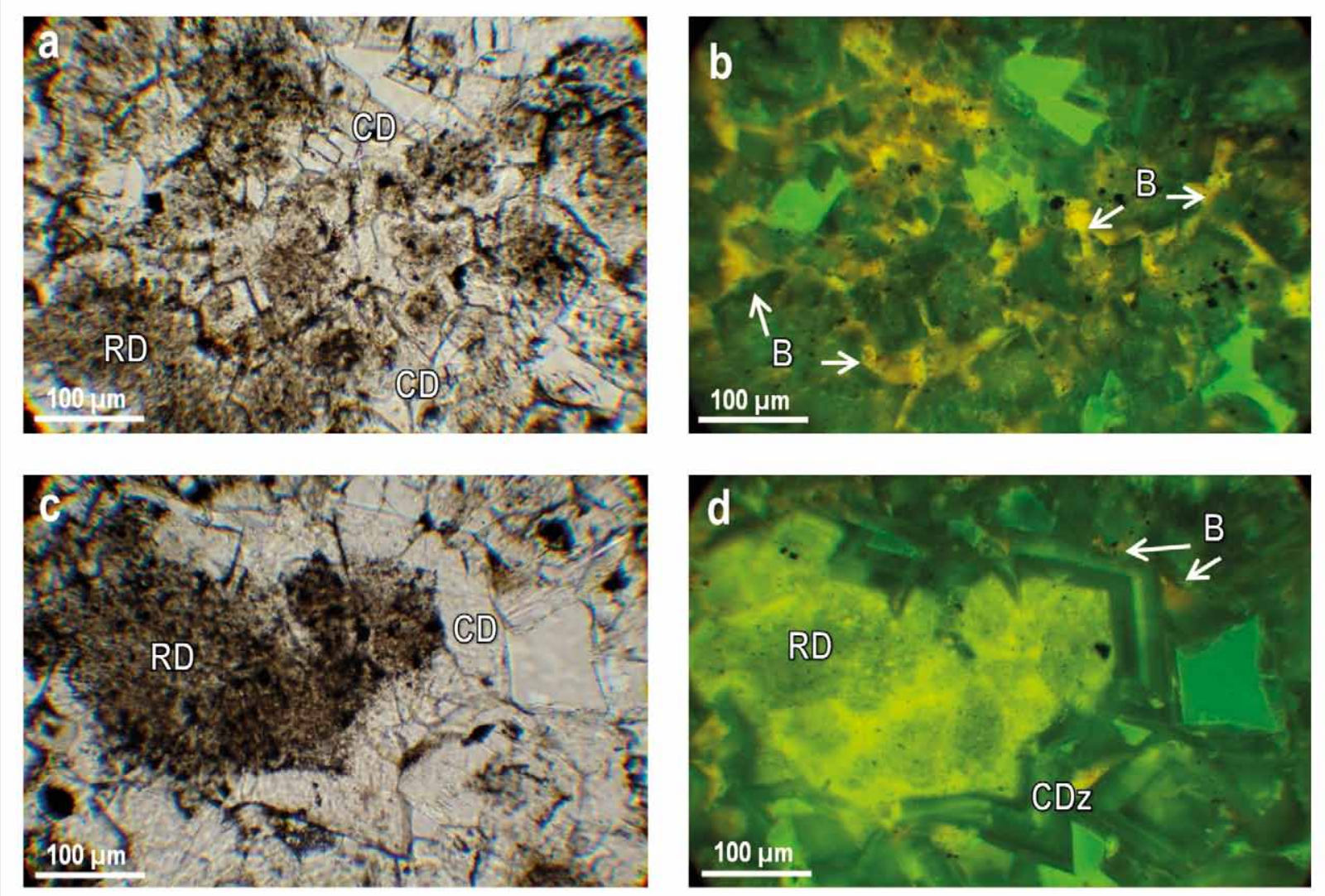

Fig. 3: KOE6 - a) replacement dolomite (RD), cementation dolomite (CD), PPL, b) the same field in fluorescent light, FL, solid bitumen (B) in the dolomite intercrystalline space, c) micrite and replacement dolomite (RD) and cementation dolomite (CD) in PPL, d) the same as c but in FL: micritic partly dolomitized allochems, probably fossil (RD), zonal cementation dolomite (CDz).

- several types of calcite and dolomite grains occur in partly dolomitized limestones;

- isopachous, syntaxial and dolomitic cements occur in the studied carbonate rocks;

- at least two generations of dolomite affect the porosity and permeability: 1. non-zonal replacement dolomite formed during the early dolomitization phase and 2. zonal cementation dolomite;

- zonal dolomites probably reflects fluctuation in formation water chemistry during the diagenesis;

- early cementation decrease the porosity and permeability while later dolomitization creates new pore space;

- fissures associated with newly formed dolomite crystals are visible only in fluorescent light;
- additional details in the recrystallized allochems visible in fluorescent light provide potential use of the method in further paleontological studies;

- intercrystalline porosity filled with bitumen provides evidence of fluid migration prior to the late stage cementation.

\section{Acknowledgements}

The paper was prepared within a project „Jurassic reservoirs cementation in the SE part of the Bohemian Massif", supported by the Czech Geological Survey (DKRVO/ C GS 2020 , project 310450 ). The authors are greatly indebted to the reviewers, who significantly helped to improve the text. 


\section{References}

Adámek, J. (2005). The Jurassic floor of the Bohemian Massif in Moravia - Geology and paleogeography. - Bulletin of Geosciences, $80,4,291-305$.

Dravis, J. J., Yurewicz, D. (1985). Enhanced carbonate petrography using fluorescence microscopy. - Journal of Sedimentary Petrology, 55, 6, 795-804.

Dunham, R. J. (1962). Classification of carbonate rocks acccording to their depositional texture. -In: Ham W. E. (ed): Classification of carbonate rocks. - AAPG Memoir 1, Tulsa, 108-121.

Eliáš, M. (1974). Microfacial examination of carbonates in petroleum prospecting areas: examples from the autochthonous Jurassic of the SE slopes of the Bohemian Massif. - Zemní plyn a nafta, 19, 3, 359-374 (in Czech).

Eliáš, M. (1981). Facies and paleogeography of the Jurassic of the Bohemian Massif. - Sborník geologických věd, Geologie, 35, 75-144.

Pícha, J. F., Stráník, Z., Krejčí, O. (2006). Geology and hydrocarbon resources of the outer West Carpathians and their foreland, Czech Republic. - In: Golonka, J., Pícha, J. F. (eds): The Carpathians and their foreland: Geology and hydrocarbon resources. AAPG Memoir 84, 49-175.

Řehánek, J. (1992). Malmian carbonate microfacies of the SE slopes of the Bohemian Massif. - MS PřF MU Brno (in Czech).

Řehánek, J. (2000). Regional geological evaluation of the Jurassic of the SE slopes of the Bohemian Massif. Investigation of the deep structure of the Dambořice Group of Autochthonous Palaeogene. - MS Czech Geological Survey. Praha, 89 p.

Sibley, D. F., Gregg, J. M. (1987). Classification of dolomite rock textures. - Journal of Sedimentary Petrology, 57, 967-975. 